\title{
Atrial tachycardia ablation in patients with a functional single ventricle after the Fontan surgery
}

\author{
Paweł Derejko' ${ }^{1}$, Justyna Rybicka ${ }^{2}$, Elżbieta K. Biernacka ${ }^{2}$, Franciszek Walczak ${ }^{1}$, Mirosław Kowalski ${ }^{2}$, \\ Piotr Urbanek ${ }^{1}$, Robert Bodalski ${ }^{1}$, Michał Orczykowski ${ }^{1}$, Artur Oręziak ${ }^{1}$, Joanna Duliban ${ }^{3}$, \\ Piotr Hoffman ${ }^{2}$, Łukasz Szumowski ${ }^{1}$
}

'Department of Cardiac Arrhythmias, Institute of Cardiology, Warsaw, Poland

${ }^{2}$ Department of Congenital Heart Disease, Institute of Cardiology, Warsaw, Poland

${ }^{3}$ Student Society at the Institute of Cardiology, Warsaw, Poland

\section{A bstract}

Background: Atrial tachyarrhythmias are a leading source of morbidity and mortality after Fontan-type procedures and antiarrhythmic drug therapy is often ineffective in these patients.

Aim: To evaluate short- and long-term outcomes of radiofrequency current ablation for atrial tachycardia (AT) in patients after the Fontan procedure, and to report clinical, electrophysiological and electroanatomical characteristics of these arrhythmias. Methods: We retrospectively analysed data obtained in 8 patients ( 5 males, 3 females) after the Fontan procedure who underwent ablation for AT between 2002 and 2013. In order to compare the clinical impact of arrhythmia before and after ablation, we used the modified arrhythmia score, ranging from 0 (no arrhythmia activity) to 12 (very severe arrhythmia). In all patients, electroanatomical mapping using the CARTO system was performed, allowing semiquantification of low-voltage $(<0.5 \mathrm{mV})$ areas and scars.

Results: Seven patients had an atriopulmonary connection and 1 patient had an extracardiac conduit. The mean patient age was $9.4 \pm 3.1$ years at the time of the Fontan procedure and $26.2 \pm 4.6$ years at the time of the first ablation. A total of 18 ablations were performed with no complications, 1 to 4 (median 2.5) procedures per patient. In patients who had more than 1 ablation, the mean time from the first to the last procedure was 34.8 months (range 1-64 months). In individual patients, 1 to 4 (median 2.5) different ATs were observed, with the mean tachycardia cycle length of $334 \pm 95$ ms. In 6 patients, low-voltage area $(<0.5 \mathrm{mV})$ comprised $25-50 \%$ of the right atrium, and in two others it comprised $10-25 \%$ and $<10 \%$ of the right atrium, respectively. Seven procedures were fully successful (ablation of all ATs), 7 were partially successful (ablation of only some AT, including clinical arrhythmia, but not of all ATs) and 4 were unsuccessful (failed ablation of clinical AT). The mean procedural, fluoroscopy and ablation times were $176 \pm 54.6,13.7 \pm 5.7$ and $21.7 \pm 11.9$ min, respectively. Freedom from arrhythmia during the mean follow-up of $58.6 \pm 46$ months (range 11-127 months) since the last procedure was obtained in 4 patients. The median arrhythmia score after the last ablation was significantly reduced compared to baseline (4.5 vs. 8; $\mathrm{p}<0.05)$.

Conclusions: Catheter ablation of AT in patients after the Fontan procedure is safe but its acute and long-term efficacy is limited. Due to complex and extensive substrate, along with complex anatomy, recurrences are frequent and patients may require repeat ablation procedures. Suppression of arrhythmia is associated with an improved clinical status of the patients. Key words: Fontan procedure, atrial tachycardia, ablation

\section{Address for correspondence:}

Paweł Derejko, MD, PhD, Department of Cardiology and Internal Medicine, Medicover Hospital, Aleja Rzeczypospolitej 5, 02-972 Warszawa, Poland, tel: +48 519331 216, e-mail: pderejko@yahoo.com Received: 02.07.2015 Accepted: 22.09.2015

Kardiologia Polska Copyright (C) Polskie Towarzystwo Kardiologiczne 2016 


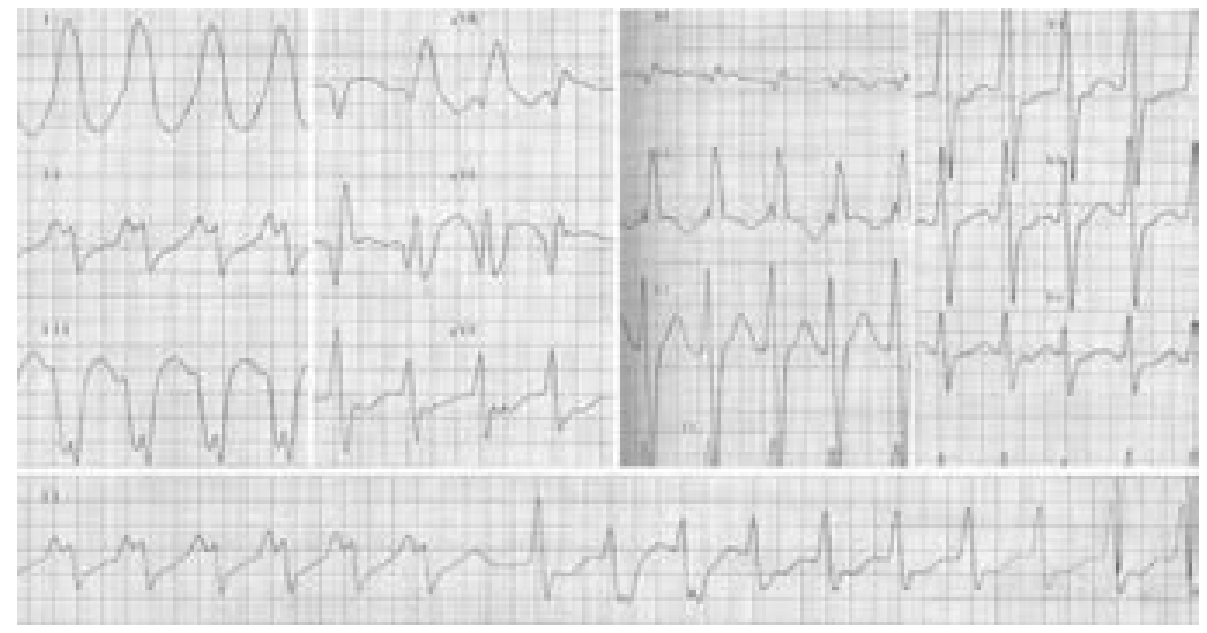

Figure 1. Atrial tachycardia (AT) with rapid ventricular response in a patient after the Fontan procedure, manifesting with syncopes. Paper speed $50 \mathrm{~mm} / \mathrm{s}$. Rapid ventricular rate results from AT with the cycle length of about $300 \mathrm{~ms}$ and 1:1 conduction. $\mathrm{P}$ waves of the tachycardia are not clearly seen. In the initial part of the tracing, QRS complex widening to about $180 \mathrm{~ms}$ due to aberration is seen in the limb leads. In the later part of this tracing and in precordial leads, QRS duration is about $110 \mathrm{~ms}$, and QRS complexes are characterised by a right bundle branch block morphology

\section{INTRODUCTION}

The term "functionally single ventricle" refers to congenital heart disease (CHD) without two normally developed ventricles or one of the atrioventricular valves, or when a repair surgery with creation of biventricular circulation is not possible due to atrioventricular valve straddling.

The purpose of the Fontan procedure is to separate systemic and pulmonary circulation. In a Fontan circulation, systemic venous return is diverted directly to the pulmonary arteries, bypassing the ventricle. Inferior vena cava return to the pulmonary arteries is obtained by creation of an intraatrial lateral tunnel (LT) which connects the vena cava inferior with the right pulmonary artery and is formed partially from the atrial wall and partially from a patch [1]. Another technique that allows connecting the vena cava inferior with the right pulmonary artery without atrial involvement is an extracardiac conduit (ECC) [2]. In the past, the right atrium (RA) was connected to the pulmonary artery (PA) but this procedure, known as atriopulmonary (RA-PA) connection, is no longer performed due to frequent complications [3]. An invariable element of the Fontan procedure is bidirectional Glenn shunt, or end-to-side anastomosis of the vena cava superior with the right pulmonary artery, resulting in total cavopulmonary connection (TCPC) [4, 5].

Supraventricular tachyarrhythmias are a major complication of the Fontan circulation. Occurrence of atrial tachycardia (AT) in a patient after the Fontan procedure may result in a significant worsening of the clinical status, often leading to the development or worsening of heart failure, syncope, or even death (Fig. 1) [6, 7]. Persistent arrhythmia with rapid ventricular response may lead to impaired function of the single ventricle, and systolic and diastolic dysfunction of the single ventricle may in turn result in the development or worsening of the atrioventricular valve regurgitation. In addition, haemodynamic disturbances associated with AT lead to venous stasis and thus predispose to thrombosis [8]. Antiarrhythmic drug therapy is of a limited effectiveness, may result in clinically significant bradycardia, and may lead to further ventricular function impairment [9]. For these reasons, ablation of AT substrate is currently an important therapeutic option in this patient group.

The aim of the study was to evaluate short- and long-term outcomes of AT ablation in patients after the Fontan procedure, and to report clinical, electrophysiological and electroanatomical characteristics of these arrhythmias.

\section{METHODS \\ Study population}

We retrospectively analysed data obtained in 8 patients ( 5 males, 3 females) after the Fontan procedure who underwent ablation for drug-refractory AT between 2002 and 2013. At the time of ablation, 7 patients had an RA-PA connection and 1 patient had TCPC with ECC.

\section{Arrhythmia score}

To allow objective assessment of the clinical importance of AT, we used the modified arrhythmia score which was previously proposed for the evaluation of patients with arrhythmia following surgery for CHD [10]. It is a sum of 4 components that describe and categorise: (1) maximum duration of the arrhythmia, (2) arrhythmia-related symptoms; (3) methods to terminate arrhythmia; and (4) antiarrhythmic therapy to prevent further episodes. Score values range from 0 (no arrhythmia activity) to 12 (very severe arrhythmia) (Table 1). 
Table 1. Modified arrhythmia score

\begin{tabular}{|lc|lc|}
\hline Type of arrhythmia & Score & Termination of arrhythmia & Score \\
\hline No documented arrhythmia & 0 & Spontaneous & 0 \\
Unsustained arrhythmia & 1 & Drugs & 1 \\
Sustained arrhythmia & 2 & Single cardioversion & 2 \\
Persistent arrhythmia & 3 & Multiple cardioversions & 3 \\
\hline Symptoms related to arrhythmia & Score & Antiarrhythmic therapy & Score \\
\hline Asymptomatic arrhythmia & 0 & No AA drugs/digoxin & 0 \\
Palpitation & 1 & Class II or IV (BB or CA) & 1 \\
Syncope/CHF/thrombosis/cyanosis & 2 & Class I or III & 2 \\
Cardiac arrest & 3 & Adverse effects of amiodarone & 3 \\
\hline
\end{tabular}

The modified arrhythmia score is a sum of four components that describe and categorize: (1) maximum duration of the arrhythmia, (2) arrhythmia-related symptoms; (3) methods to terminate arrhythmia; and (4) antiarrhythmic therapy to prevent further episodes. Each component is scored from 0 to 3, and the maximum score is 12; AA - antiarrhythmic; BB - beta-blocker; CA — calcium antagonist; CHF - congestive heart failure

Use of this score allows comparisons of the severity of arrhythmia, arrhythmia-related symptoms and treatment used before and after the ablation. In the study group, we evaluated the modified arrhythmia score before the first and after the last ablation.

\section{Electrophysiological testing and ablation}

Before ablation, each patient gave written informed consent for the procedure, the wording of which was previously accepted by the local bioethics committee. Intracardiac leads were introduced through the femoral vessels. Twelve-lead surface electrocardiogram (ECG) and intracardiac electrograms were recorded using electrophysiology systems (EP MedSystems, West Berlin, NJ, USA, or Bard, Bard Electrophysiology Division C.R. Bard, Inc. Lowell, MA, USA). An electroanatomic mapping system (CARTO, Biosense Webster, Inc., Diamond Bar, CA, USA) was also used during each procedure to create anatomic, potential, and activation maps. In each patient, we used a flexible 4-polar diagnostic catheter placed in a stable location, preferably the coronary sinus. In patients with RA-PA connection, leads were introduced to the atrium via the inferior vena cava, and in the patient with ECC using a retrograde approach through the aorta, ventricle, and the atrioventricular valve. Following lead placement, heparin was administered in an initial dose of 50-100 U/kg, followed by $1000 \mathrm{U}$ each hour. Two ablation procedures were performed using an $8 \mathrm{~mm}$ tip catheter (Navistar, DS, Biosense Webster, Diamond Bar, CA, USA), and the others using a $3.5 \mathrm{~mm}$ irrigated tip catheter (Navistar, Thermocool, Biosense Webster, Diamond Bar, CA, USA). Maximum power during the ablation did not exceed 60 Watt when using the $8 \mathrm{~mm}$ tip catheter and 42 Watt when using the irrigated tip catheter. The extent of the ablation depended on the clinical situation and was left to the operator's discretion. First, an atrial map was created. In patients with persistent AT at baseline, the CARTO map was created during the arrhythmia. The aim of mapping was to visualise the reentry circuit or the focal origin of the focal tachycardia, and to visualise scars and low-amplitude areas (Figs. 2, 3). In patients with sinus rhythm at baseline, the potential map was created during pacing, and programmed stimulation was then attempted to induce tachycardia. The choice of sites for ablation was based on the analysis of potential and activation maps along with entrainment pacing. During the procedure, we aimed to terminate the arrhythmia by ablation. If this was not possible, antitachycardia pacing was used at the end of the procedure, followed by electrical cardioversion if pacing was ineffective. In patients in whom tachycardia was terminated during radiofrequency (RF) current application, following the ablation we evaluated whether the arrhythmia remained inducible by performing programmed stimulation (up to 2 extrastimuli) and rapid pacing up to the cycle length of 250-220 ms or the atrial refractory period. In patients in whom the ablation of the cavo-tricuspid isthmus was performed, the endpoint was to obtain a conduction block in this area. Similarly, if the ablation was performed between two non-conducting areas (e.g., scar-scar or scar-conduit), we also aimed to create a conduction block in these areas.

\section{Electroanatomical evaluation of the atrium}

To evaluate the degree of right atrial damage, we used CARTO maps to estimate the size of scar and low-amplitude areas. The evaluation was made visually in 4 perpendicular views (anterior, left lateral, right lateral, and posterior) for the cut-off points of $<0.5 \mathrm{mV}$ and $<1 \mathrm{mV}$. We determined whether areas described by the above parameters comprised the following proportions of the atrial size: $<10 \%, 10-25 \%$, $25-50 \%, 50-75 \%$, or $>75 \%$ (Figs. 2, 3). Due to semiquantitative nature of this assessment, evaluation was performed twice several days apart. If the results obtained during these 

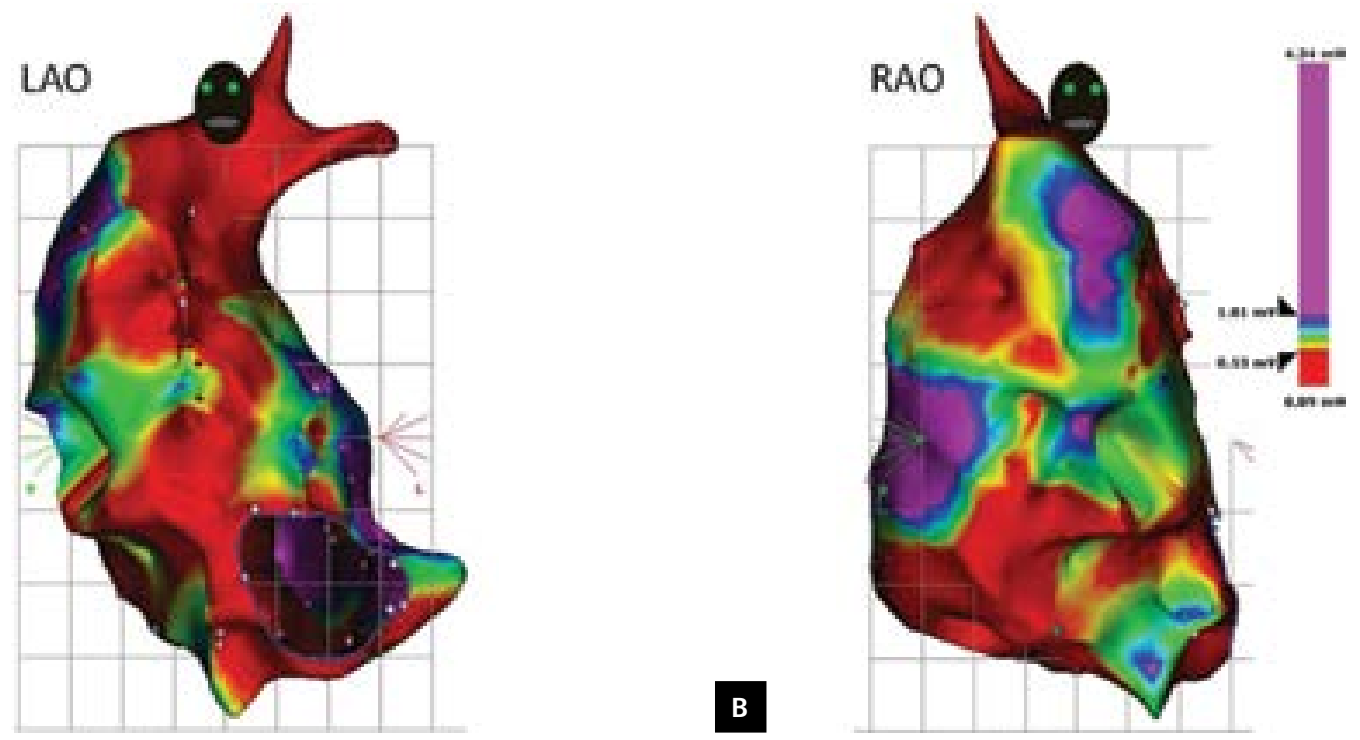

Figure 2. Atrial potential map. Colour-coded atrial potential map in the left anterior oblique (LAO; $\mathbf{A})$ and the right anterior oblique (RAO; B) views. Colour coding scale is shown to the right. Areas with the voltage of $<0.5 \mathrm{mV}$ are coded red, and those with the voltage of $>1 \mathrm{mV}$ are coded pink. Areas with the voltage in the range of $0.5-1.0 \mathrm{mV}$ are coded with the remaining colours. In the views showed, most of the right atrium shows the voltage of $<1 \mathrm{mV}$, and areas with the voltage of $<0.5 \mathrm{mV}$ comprise up to $50 \%$ of the atrial area
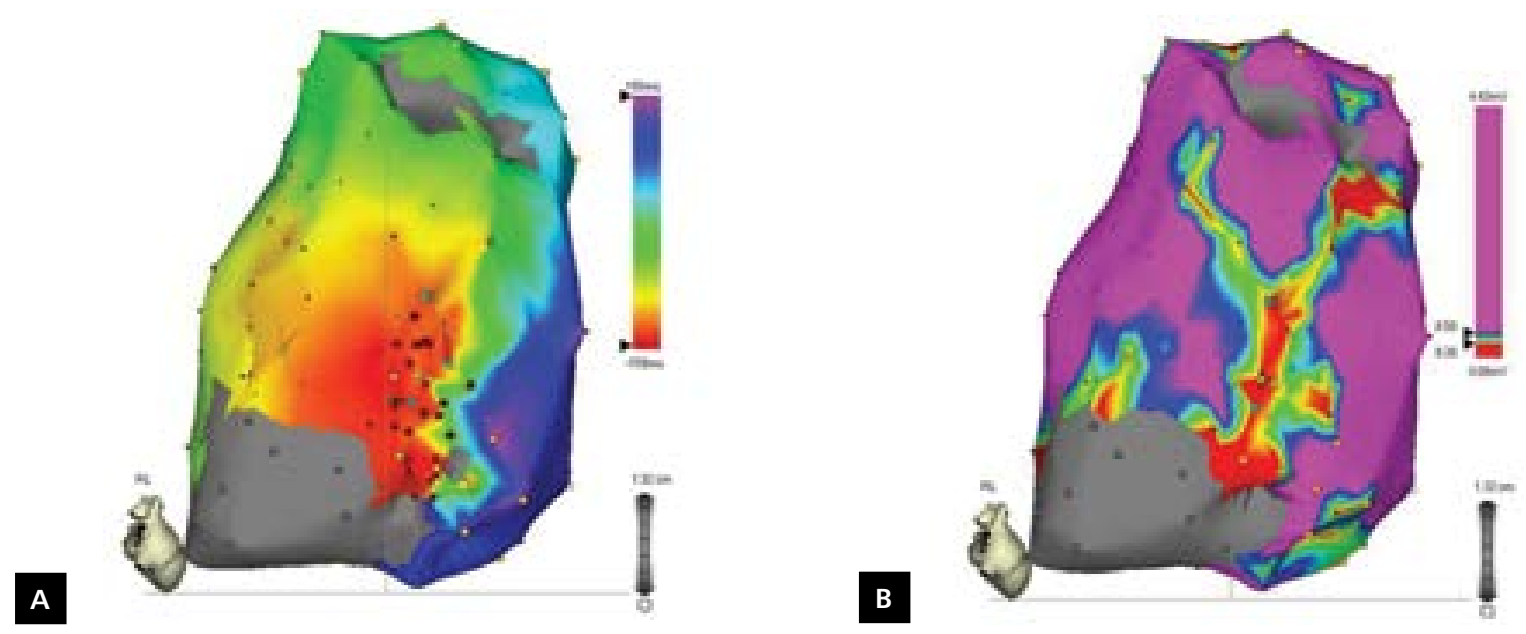

Figure 3. Atrial potential and activation maps during tachycardia. Colour-coded right atrial potential (A) and activation (B) maps in the right lateral view in a patient with atrial tachycardia (AT). Scar areas are shown in grey. A. The reentry circuit of an AT with the cycle length of $320 \mathrm{~ms}$ was mapped entirely to the lateral wall of the right atrium. Red indicates the earliest $(-158 \mathrm{~ms})$ and pink the latest (155 ms) activation. Blue dots indicate places where dual potentials were recorded, consistent with functional conduction block. Yellow dots indicate sites of entrainment pacing. Burgundy dots indicate places of radiofrequency current application; B. The reentry circuit of the tachycardia was mapped to low-amplitude ( $<0.5 \mathrm{mV})$ area adjacent to scar

two occasions differed, the result with less low-amplitude areas was considered the final assessment.

\section{Characteristics of the recorded arrhythmia}

For all clinical and induced arrhythmias, we attempted to map its reentry circuit or the focal origin using the electroanatomical mapping system and also entrainment pacing if possible. The tachycardia was considered reentrant if $>75 \%$ of AT cycle could be mapped and/or entrainment pacing confirmed the reentrant nature of the arrhythmia. Focal arrhythmia was defined as regular or irregular tachycardia originating within a limited area, characterised by a concentric activation within the atria. If more than one tachycardia was identified, different AT morphologies were diagnosed if: (1) a change in 
Table 2. Clinical data and treatment outcomes

\begin{tabular}{|c|c|c|c|c|c|c|c|c|c|c|}
\hline $\begin{array}{l}\text { Patient } \\
\text { no. }\end{array}$ & Gender & $\begin{array}{c}\text { Age } \\
\text { [years] }\end{array}$ & $\begin{array}{c}\text { Age at } \\
\text { Fontan } \\
\text { proce- } \\
\text { dure } \\
\text { [years] }\end{array}$ & $\begin{array}{c}\text { Time } \\
\text { from } \\
\text { Fontan } \\
\text { proce- } \\
\text { dure to } \\
\text { ablation } \\
\text { [years] }\end{array}$ & $\begin{array}{c}\text { Type of } \\
\text { single } \\
\text { ventricle }\end{array}$ & $\begin{array}{l}\text { Type of } \\
\text { Fontan } \\
\text { circula- } \\
\text { tion }\end{array}$ & $\begin{array}{l}\text { Number } \\
\text { of abla- } \\
\text { tions }\end{array}$ & $\begin{array}{c}\text { Time } \\
\text { from the } \\
\text { first to } \\
\text { the last } \\
\text { ablation } \\
\text { [months] }\end{array}$ & $\begin{array}{l}\text { Dura- } \\
\text { tion of } \\
\text { follow- } \\
\text {-up after } \\
\text { the last } \\
\text { ablation } \\
\text { [months] }\end{array}$ & $\begin{array}{l}\text { Long-term } \\
\text { outcomes }\end{array}$ \\
\hline 1 & M & 20 & 12 & 8 & DRV & ECC & 1 & - & 127 & $\begin{array}{c}1 \text { episode of AT } \\
\text { requiring electrical } \\
\text { cardioversion (sotalol) }\end{array}$ \\
\hline 2 & M & 21 & 4 & 17 & DLV & RA-PA & 3 & 9 & 90 & $\begin{array}{c}\text { No arrhythmia } \\
\text { (sotalol) }\end{array}$ \\
\hline 3 & $\mathrm{~F}$ & 28 & 10 & 18 & DLV & RA-PA\# & 2 & 1 & 102 & $\begin{array}{c}\text { No arrhythmia } \\
\text { (sotalol) }\end{array}$ \\
\hline 4 & $\mathrm{~F}$ & 23 & 6 & 17 & DLV & RA-PA & 3 & 58 & 79 & Permanent AF \\
\hline 5 & M & 29 & 12 & 17 & DLV & RA-PA & 4 & 42 & 11 & No arrhythmia (BB) \\
\hline 6 & M & 27 & 11 & 16 & DLV & RA-PA\# & 1 & - & 19 & $\begin{array}{l}\text { AT episodes requir- } \\
\text { ing admission at } \\
5 \text { months after abla- } \\
\text { tion (amiodarone) }\end{array}$ \\
\hline 7 & $\mathrm{~F}$ & 34 & 10 & 24 & DLV & RA-PA\# & 4 & 64 & 29 & Permanent AF/death \\
\hline 8 & M & 26 & 11 & 15 & DLV & RA-PA & 1 & - & 13 & No arrhythmia \\
\hline
\end{tabular}

\#Conversion to ECC after the last ablation; AF — atrial fibrillation; AT — atrial tachycardia; BB — beta-blocker; DLV — dominant left ventricle; DRV — dominant right ventricle; ECC — extracardiac conduit; F — female; M - male; RA-PA — atriopulmonary connection

the $\mathrm{P} / \mathrm{F}$ wave morphology was observed in the surface ECG; (2) a change in the direction of activation/origin site of the tachycardia was observed; or (3) a significant change in the cycle length ( $\pm 20 \mathrm{~ms}$ ) was seen in association with a change of the reentry circuit/focal origin of the tachycardia.

\section{Immediate ablation success}

The ablation procedure was considered effective if all ATs were terminated, both clinical and induced, and no persistent arrhythmia was induced during the electrophysiological study (EPS) after the procedure. The ablation procedure was considered partially effective if clinical AT was terminated but not all tachycardia induced during EPS could be terminated. The ablation procedure was considered ineffective if clinical AT could not be terminated.

\section{Long-term outcomes}

Following the procedure, the patients were monitored for ablation efficacy at 4-12 weeks and then every 3-6 months. During the follow-up visits, ECG was performed, along with Holter monitoring at least once a year. In addition, conventional ECG and/or Holter monitoring was performed whenever the patient reported recurrent palpitation. The arrhythmia recurrence was defined as recurrent atrial flutter, AT or atrial fibrillation recorded in ECG or each palpitation lasting more than $3 \mathrm{~min}$ if it occurred past 6 weeks after the ablation and was of a similar nature to the symptoms occurring before the ablation. If dictated by the clinical situation, e.g. tachycardia with significant symptoms persisted after the ablation, a repeated ablation was performed before 6 weeks after the previous ablation (Table 2, patient No. 3). Follow-up echocardiographic examination was performed after each ablation procedure and at least once a year during long-term follow-up.

\section{Statistical analysis}

Continuous variables were reported as mean values \pm standard deviation. For non-normally distributed variables, we also reported medians and ranges. Quantitative variables were compared using the Wilcoxon test. $\mathrm{P}<0.05$ was considered statistically significant. Statistical analysis was performed using the Statistica 5.0 software (StatSoft, Inc., Tulsa, OK, USA).

\section{RESULTS}

Detailed data on the study population and ablation outcomes are given in Tables 2 and 3. The mean patient age was $9.4 \pm 3.1$ years at the time of the Fontan procedure and $26.2 \pm 4.6$ years at the time of the first ablation. The mean time from the Fontan procedure to the first ablation was $16.5 \pm 4.4$ years. A total of 18 ablations were performed with no complications, 1 to 4 (median 2.5) procedures per patient. 


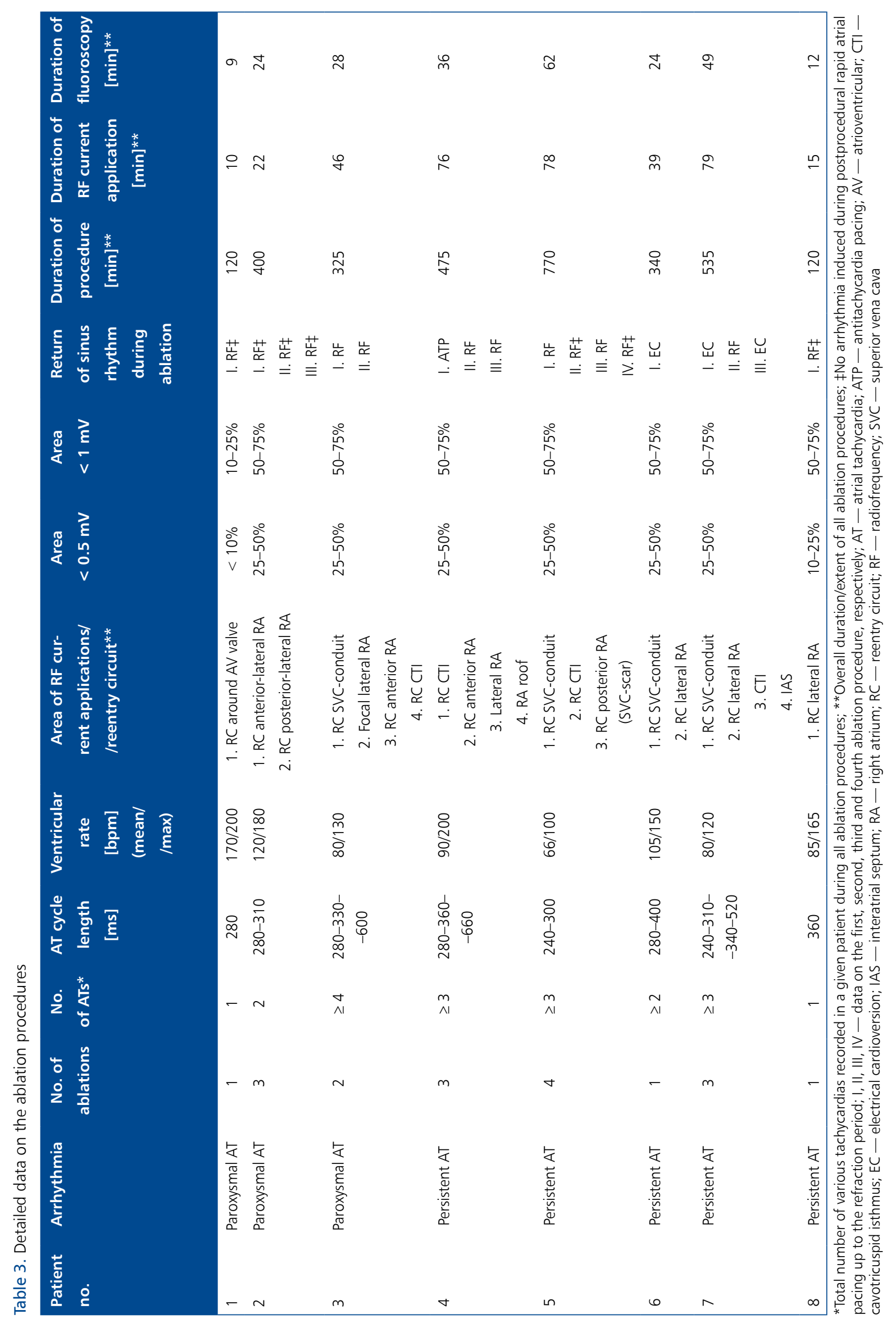




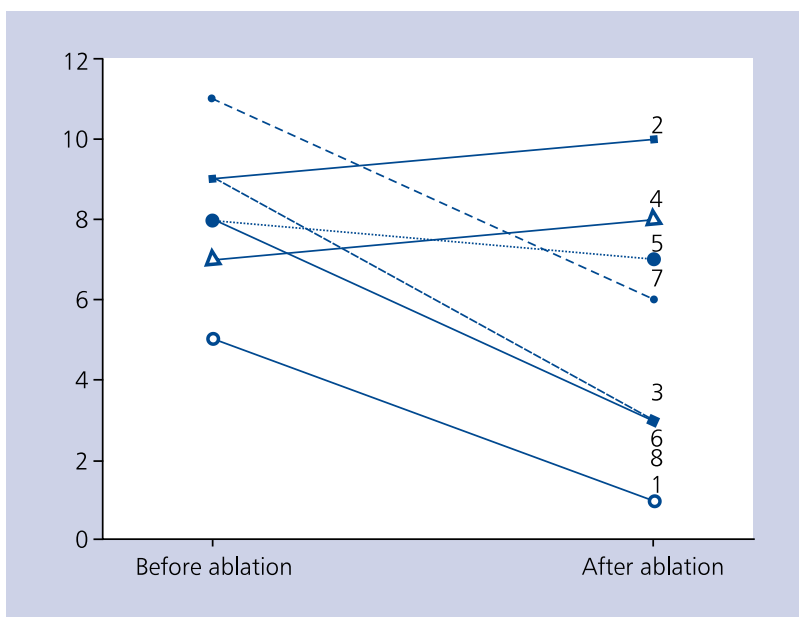

Figure 4. Modified arrhythmia score values in individual patients before and after ablation

In patients who had more than 1 ablation, the mean time from the first to the last procedure was 34.8 months (range 1-64 months). In individual patients, 1 to 4 (median 2.5) different ATs were observed during the procedure, with the mean tachycardia cycle length of $334 \pm 95 \mathrm{~ms}$. The area of significant damage with low voltage of $<0.5 \mathrm{mV}$ comprised $25-50 \%$ of the right atrium in 6 patients, and $<10 \%$ of the common atrium in the single patient with ECC. In all patients with RA-PA connections, voltage $<1 \mathrm{mV}$ was recorded over $50-75 \%$ of the atrium.

Seven procedures were fully successful, 7 were partially successful, and 4 were unsuccessful. The mean procedural, fluoroscopy and RF current application times were $176 \pm 54.6,13.7 \pm 5.7$ and $21.7 \pm 11.9$ min, respectively. Freedom from arrhythmia during the mean follow-up of $58.6 \pm 46$ months (range 11-127 months) since the last procedure was obtained in 4 patients. The median arrhythmia score was 4.5 after the last ablation compared to 8 before the first ablation ( $<<0.05$ ) (Fig. 4).

Conversion to ECC was performed in 3 patients after the last ablation procedure. In this subgroup, 1 patient (No. 3) remains without significant arrhythmia, 1 patient (No. 7) died in the periprocedural period, and in the remaining patient (No. 6), with persistent tachycardia refractory to cardioversion at baseline, arrhythmia did not recur during short- and mid-term follow-up, which resulted in a significant improvement of the clinical status and an increase in the ventricular ejection fraction from $30 \%$ to $60 \%$. Five months after the ablation and 1 month after conversion to ECC with intraprocedural ablation, episodes of tachycardia with rapid ventricular rate developed, and the patient required hospital admission and electrical cardioversion. In this patient access to the atrium is very difficult due to the use of ECC without fenestration and the presence of a mitral valve prosthesis. The patient receives amiodarone which is partially effective.

\section{DISCUSSION}

Atrial tachycardias are a leading source of morbidity and mortality in patients after Fontan-type procedures $[6,7,11]$. Among patients with RA-PA connection that was performed in the past, the proportion of patients with supraventricular arrhythmia at 20 years after the surgery may be as high as 50\% $[12,13]$. In case of $L T$ that was performed during a later period and currently preferred ECC, these proportions are 6-35\% and $2-28 \%$, respectively [14-16]. Thus, studies suggest that the incidence of arrhythmia is lower in patients with LT and ECC compared to those with RA-PA connection. Of note, however, the duration of long-term follow-up in patients with LT and ECC is significantly shorter compared to those with RA-PA connection. Thus, comparisons of arrhythmia incidence in these patient groups and evaluation of potential advantage of LT and ECC over RA-PA connection require further studies. At the same time, the access to the arrhythmia substrate within the atrium may be much more difficult with these two latter modifications of the Fontan procedure, particularly in case of ECC without fenestration, requiring puncture of the tunnel or conduit, or a retrograde approach through the aorta. This may render effective ablation procedure much more difficult or impossible $[17,18]$. An example of these difficulties is our patient No. 6 after conversion to ECC. For these reasons, it seems justified to perform a fenestration between the conduit and the atrium in all patients with ECC if technically and clinically (degree of desaturation) feasible. In case of a retrograde approach through the aorta, lead manoeuvring in the atrium is very difficult and some areas may be impossible to reach. Remote magnetic navigation systems are a significant improvement in such a situation, as they allow reaching nearly all atrial areas, which translates to better ablation outcomes [19]. Unfortunately, such systems are currently unavailable in Poland.

Our results indicate limited short-term efficacy of the procedures and a high rate of arrhythmia recurrences following AT ablation in this patient group. This led to a high number of ablation procedures despite a small number of patients. However, the mean interval between subsequent ablation procedures was quite long, which indicates at least temporary efficacy of the procedures and may suggest progressive atrial remodelling and disease progression. Similar observations regarding progressive atrial remodelling were made by Correa et al. [20] who performed ablation in 32 patients with a Fontan-type circulation in whom TCPC was performed.

Literature data indicate that short-term efficacy of ablation in patients after the Fontan procedure is $43-83 \%$, and the recurrence rate during long-term follow-up (up to 4 years) is $32-76 \%[10,20-22]$. In a recent study that 
reported ablation outcomes in 19 patients after the Fontan procedure, only $3(15 \%)$ patients were free from arrhythmia recurrence at 4 years of follow-up [22]. These results are clearly worse compared to patients with other CHD, both simple and complex [22]. One reason for limited efficacy of ablation in patients after the Fontan procedure, particularly those with RA-PA connection, is significant right atrial dilation along with extensive fibrosis and wall thickening. The degree of atrial enlargement correlated with the extent of structural damage which may be visualised using electroanatomical mapping systems as scar and low amplitude areas [23, 24]. In the studies by Yap et al. [23] and Abrams et al. [24], the proportion of right atrial areas with a voltage of $<0.5 \mathrm{mV}$ was $44 \%$ and $38 \%$, respectively. These values were significantly higher compared to patients after repair of other CHD. Our findings are consistent with these observations. These extensive damage areas are a result of scarring following previous surgery on one hand, and an increased right atrial pressure on the other hand, particularly in case of RA-PA connection. Atrial wall thickening and fibrosis secondary to elevated atrial pressure may render transmural damage more difficult to obtain during the ablation procedure which also translates to less favourable treatment outcomes. High atrial pressure persisting after the ablation may lead to further damage which may be an origin of new arrhythmia or sustain a reentry circuit [20, 22]. In addition, high desaturation before the Fontan procedure may damage cardiomyocytes and alter gene expression, leading to permanent proarrhythmic structural and functional changes [25].

Another reason for limited ablation efficacy may be multiple reentry circuits and arrhythmia foci in individual patients, as well as their atypical location, i.e. outside the cavotricuspid isthmus $[22,26]$. In our study group, the median number of different AT morphologies was 2.5 per patient. The presence of several reentry circuits of different foci of tachycardia makes their identification and effective ablation much more difficult.

Despite these limitations, ablation as a component of comprehensive treatment approach may contribute to improvement of the clinical status in treated patients. This does not necessarily mean that arrhythmia is completely suppressed and/or drug treatment can be stopped. However, a significant reduction of the number and severity of tachycardias, leading to a reduced need for hospitalisation and cardioversion, translates to an improved patient well-being. Thus, evaluation of the treatment outcomes in patients after a surgery for CHD should be based on several parameters or multicomponent indexes, such as the proposed arrhythmia score [10]. On the other hand, such score does not always show all benefits from the ablation. The example could be our patient No. 1 who remained free from clinically significant arrhythmia for several years after the ablation. The reason for high arrhythmia score during long-term follow-up was a single episode of tachycardia with significant clinical symptoms requiring cardioversion that occurred several years after the ablation. Somewhat different situation occurred in our patient No. 6, in whom arrhythmia recurred several months after the ablation but the procedure allowed effective treatment of persistent tachycardia with rapid ventricular rate, leading to impaired ventricular function.

Finally, it should be noted that presence of ATs in patients after a repair surgery for CHD, and particularly in patients after the Fontan procedure, is associated with a relatively high mortality of about $1.8 \%$ per year $[10,11]$. Such a high mortality indicates low haemodynamic compensation capabilities in the setting of atrial tachyarrhythmia in patients with congenital heart disease.

\section{Limitations of the study}

The study group was small and statistical analysis of such a small samples is prone to errors. The study population was not entirely homogenous, with RA-PA connection in 7 patients and TCPC with ECC in 1 patient. Our results and conclusions may refer mostly to patients with RA-PA connection.

\section{CONCLUSIONS}

Catheter ablation of AT in patients after the Fontan surgery is safe but its acute and long-term efficacy is limited due to complex and extensive substrate along with complex anatomy. For these reasons, good outcomes may require performing more than 1 ablation procedure. Suppression of arrhythmia is associated with an improved clinical status of the patients.

\section{Conflict of interest: none declared}

\section{References}

1. de Leval MR, Kilner P, Gewillig M, Bull C. Total cavopulmonary connection: A logical alternative to atriopulmonary connection for complex Fontan operations. Experimental studies and early clinical experience. J Thorac Cardiovasc Surg, 1988; 96: 682-695.

2. Marcelletti C, Corno A, Giannico S, Marino B. Inferior vena cava-pulmonary artery extracardiac conduit. A new form of right heart bypass. J Thorac Cardiovasc Surg, 1990; 100: 228-232.

3. Fontan F, Baudet E. Surgical repair of tricuspid atresia. Thorax, 1971; 26: 240-248.

4. Mazzera E, Corno A, Picardo S et al. Bidirectional cavo-pulmonary shunts: clinical applications as staged or definitive palliation. Ann Thorac Surg, 1989; 47: 415-420.

5. Hopkins RA, Armstrong BE, Serwer GA et al. Physiological rationale for a bi-directional cavopulmonary shunt. J Thorac Cardiovasc Surg, 1985; 90: 391-398.

6. Garson A Jr, Bink-Boelkens M, Hesslein PS et al. Atrial flutter in the young: a collaborative study of 380 cases. J Am Coll Cardiol, 1985; 6: 871-878.

7. Diller GP, Giardini A, Dimopoulos K et al. Predictors of morbidity and mortality in contemporary Fontan patients: results from a multicenter study including cardiopulmonary exercise testing in 321 patients. Eur Heart J, 2010; 31: 3073-3083. doi: 10.1093/eurheartj/ehq356.

8. Walker HA, Gatzoulis MA. Prophylactic anticoagulation following the Fontan operation. Heart, 2005; 91: 854-856. doi: 10.1136/hrt.2004.039073. 
9. Weindling SN, Saul JP, Triedman JK, Walsh EP. Recurrent intra-atrial reentry tachycardia following congenital heart disease surgery: the search for an optimum therapy. Abstract. Circulation, 1995; 92: I765.

10. Triedman JK, Alexander ME, Love BA et al. Influence of patient factors and ablative technologies on outcomes of radiofrequency ablation of intra-atrial re-entrant tachycardia in patients with congenital heart disease. J Am Coll Cardiol, 2002; 39: 1827-1835. doi: 10.1016/S0735-1097(02)01858-2.

11. Giannakoulas G, Dimopoulos K, Yuksel S et al. Atrial tachyarrhythmias late after Fontan operation are related to increase in mortality and hospitalization. Int J Cardiol, 2012; 157: 221-226. doi: 10.1016/j.ijcard.2010.12.049.

12. Gelatt M, Hamilton RM, McCrindle BW et al. Risk factors for atrial tachyarrhythmias after the Fontan operation. J Am Coll Cardiol, 1994; 24: 1735-1741. doi:10.1016/0735-1097(94)90181-3.

13. Peters NS, Somerville J. Arrhythmias after the Fontan procedure. Br Heart J, 1992; 68: 199-204. doi: 10.1136/hrt.68.8.199.

14. Stephenson EA, Lu M, Berul CI et al. Pediatric Heart Network Investigators. Arrhythmias in a contemporary Fontan cohort: prevalence and clinical associations in a multicenter cross-sectional study. J Am Coll Cardiol, 2010; 56: 890-896. doi: 10.1016/j.jacc.2010.03.079.

15. Kumar SP, Rubinstein CS, Simsic JM et al. Lateral tunnel versus extracardiac conduit Fontan procedure: a concurrent comparison. Ann Thorac Surg, 2003; 76: 1389-1396. doi: 10.1016/S00034975(03)01010-5.

16. Sarkis V, Sreeram N, Trieschmann U et al. Comparison of arrhythmia incidence after the extracardiac conduit versus the intracardiac lateral tunnel Fontan completion. Int J Cardiol, 2011; 146: 258-259. doi: 10.1016/j.ijcard.2010.10.070.

17. Khairy P, Poirier N. Is the extracardiac conduit the preferred Fontan approach for patients with univentricular hearts? The extracardiac conduit is not the preferred Fontan approach for patients with univentricular hearts. Circulation, 2012; 126: 2516-2525. doi: 10.1161/CIRCULATIONAHA.111.075036.

18. Dave AS, Aboulhosn J, Child JS, Shivkumar K. Transconduit puncture for catheter ablation of atrial tachycardia in a patient with extracardiac Fontan palliation. Heart Rhythm, 2010; 7: 413-416. doi: 10.1016/j.hrthm.2009.10.037.

19. Ueda A, Suman-Horduna I, Mantziari L et al. Contemporary outcomes of supraventricular tachycardia ablation in congenital heart disease: a single-center experience in 116 patients. Circ Arrhythm Electrophysiol, 2013; 6: 606-613. doi: 10.1161/CIRCEP.113.000415.

20. Correa B, Sherwin ED, Kovach J et al. Mechanism and ablation of arrhythmia following total cavopulmonary connection. Circ Arrhythm Electrophysiol, 2015; 8: 318-325. doi: 10.1161/CIRCEP.114.001758.

21. Weipert J, Noebauer C, Schreiber $\mathrm{C}$ et al. Occurrence and management of atrial arrhythmia after long-term Fontan circulation. J Thorac Cardiovasc Surg, 2004; 127: 457-464. doi: 10.1016/j. jtcvs.2003.08.054.

22. Yap SC, Harris L, Silversides CK et al. Outcome of intra-atrial re-entrant tachycardia catheter ablation in adults with congenital heart disease: negative impact of age and complex atrial surgery. J Am Coll Cardiol, 2010; 56: 1589-1596. doi: 10.1016/j. jacc.2010.04.061

23. Yap SC, Harris L, Downar E et al. Evolving electroanatomic substrate and intra-atrial reentrant tachycardia late after Fontan surgery. J Cardiovasc Electrophysiol, 2012; 23: 339-345. doi: 10.1111/j.1540-8167.2011.02202.x.

24. Abrams DJ, Earley MJ, Sporton SC et al. Comparison of noncontact and electroanatomic mapping to identify scar and arrhythmia late after the Fontan procedure. Circulation,2007; 115: 1738-1746. doi: 10.1161/CIRCULATIONAHA.106.633982.

25. Del Duca D, Tadevosyan A, Karbassi F et al. Hypoxia in early life is associated with lasting changes in left ventricular structure and function at maturity in the rat. Int J Cardiol, 2012; 156: 165-173. doi: 10.1016/j.ijcard.2010.10.135.

26. Triedman JK, Bergau DM, Saul JP et al. Efficacy of radiofrequency ablation for control of intraatrial reentrant tachycardia in patients with congenital heart disease. J Am Coll Cardiol, 1997; 30: 1032-1038. doi: 10.1016/S0735-1097(97)00252-0.

Cite this article as: Derejko P, Rybicka J, Biernacka EK et al. Atrial tachycardia ablation in patients with a functional single ventricle after the Fontan surgery. Kardiol Pol, 2016; 74: 762-771. doi: 10.5603/KP.a2015.0214. 


\title{
Ablacja podłoża częstoskurczów przedsionkowych u pacjentów z czynnościowo pojedynczą komorą po operacji Fontana
}

\author{
Paweł Derejko1, Justyna Rybicka², Elżbieta K. Biernacka², Franciszek Walczak $^{1}$, Mirosław Kowalski², \\ Piotr Urbanek ${ }^{1}$, Robert Bodalski ${ }^{1}$, Michał Orczykowski ${ }^{1}$, Artur Oręziak ${ }^{1}$, Joanna Duliban ${ }^{3}$, \\ Piotr Hoffman ${ }^{2}$, Łukasz Szumowski ${ }^{1}$ \\ ${ }^{1}$ Klinika Zaburzeń Rytmu Serca, Instytut Kardiologii, Warszawa \\ ${ }^{2}$ Klinika Wad Wrodzonych Serca, Instytut Kardiologii, Warszawa \\ ${ }^{3}$ Studenckie Koło Naukowe, Warszawa
}

\section{Streszczenie}

Wstęp: Częstoskurcze przedsionkowe (AT) są jedną z wiodących przyczyn chorobowości i śmiertelności u pacjentów po operacji Fontana, a skuteczność terapii lekami antyarytmicznymi w tej grupie chorych jest z reguły ograniczona.

Cel: Celem pracy była ocena wyników bezpośrednich i odległych ablacji AT u pacjentów po operacji Fontana oraz ocena charakterystyki klinicznej, elektrofizjologicznej i elektroanatomicznej arytmii.

Metody: Retrospektywną analizą objęto dane 8 pacjentów (5 mężczyzn, 3 kobiety) po operacji Fontana kierowanych na ablację w latach 2002-2013 z powodu AT. Istotność kliniczną i nasilenie arytmii przed i po ablacji oceniono za pomocą zmodyfikowanego wskaźnika arytmicznego. Jest on sumą czterech składowych wartościujących, takich jak: 1) maksymalny czas trwania arytmii, 2) objawy związane z arytmią, 3) metody przerywania arytmii, 4) terapia antyarytmiczna konieczna do zapobiegania napadom. Wskaźnik ten przyjmuje wartości od 0 (bez istotnej arytmii) do 12 punktów (ciężka arytmia). U wszystkich pacjentów zabiegi ablacji wykonywano z zastosowaniem systemu CARTO, co pozwoliło na pótilościową ocenę wielkości obszarów niskoamplitudowych $(<0,5 \mathrm{mV})$ i blizn w obrębie przedsionka.

Wyniki: $U 7$ chorych obecne było połączenie prawy przedsionek-tętnica płucna, a u 1 chorego - tunel zewnątrzsercowy. Średni wiek pacjentów w trakcie wykonania operacji Fontana wynosił 9,4 $\pm 3,1$ roku, a w trakcie wykonywania pierwszej ablacji $-26,2 \pm 4,6$ roku. W badanej grupie wykonano łącznie 18 ablacji bez istotnych powikłań, 1-4 ablacje/chorego; mediana 2,5. U pacjentów, u których przeprowadzono więcej niż 1 ablację, odstęp czasu między pierwszym a ostatnim zabiegiem wynosit średnio 34,8 miesiąca (zakres 1-64 miesiące). W trakcie zabiegów u poszczególnych pacjentów obserwowano od 1 do ponad 4 różnych morfologii częstoskurczów (mediana 2,5). Średni cykl AT wynosił $334 \pm 95$ ms. U 6 pacjentów obszary istotnego uszkodzenia z amplitudą $<0,5 \mathrm{mV}$ zajmowały $25-50 \%$ powierzchni prawego przedsionka, a u dwóch kolejnych osób, odpowiednio, 10-25\% i < 10\% jego powierzchni. Siedem ablacji było w pełni skuteczne (usunięto wszystkie AT — kliniczne i wywołane stymulacją), kolejne 7 ablacji było częściowo skuteczne (nie usunięto wszystkich arytmii, ale usunięto kliniczny AT), a 4 ablacje były nieskuteczne (nie usunięto klinicznego AT). Średnie czasy zabiegu, skopii rentgenowskiej i dostarczania energii o częstotliwości radiowej wynosity odpowiednio: $176 \pm 54,6 ; 13,7 \pm 5,7$ i 21,7 \pm 11 ,9 minut. W obserwacji odległej, średnio 58,6 \pm 46 (zakres 11-127) miesięcy po ostatniej ablacji, u 4 pacjentów nie stwierdzono arytmii. Mediana wskaźnika arytmicznego przed pierwszą ablacją wynosiła 8 punktów, a po ostatniej ablacji $-4,5$ punktu $(p<0.05)$.

Wnioski: Ablacja AT u pacjentów po operacji Fontana jest zabiegiem bezpiecznym, ale jej skuteczność bezpośrednia i odległa jest ograniczona. Wynika to z rozległego i złożonego substratu oraz trudnych warunków anatomicznych. Uzyskanie dobrych efektów może wymagać wykonania więcej niż jednej ablacji. Opanowanie arytmii przyczynia się do poprawy stanu klinicznego pacjentów.

Słowa kluczowe: operacja Fontana, częstoskurcze przedsionkowe, ablacja

Kardiol Pol 2016; 74, 8: 762-771

\section{Adres do korespondencji:}

dr hab. n. med. Paweł Derejko, Oddział Kardiologii i Chorób Wewnętrznych, Szpital Medicover, Aleja Rzeczypospolitej 5, 02-972 Warszawa, tel: +48 519 331 216, 